\title{
Corporate Voting versus Market Price Setting
}

\author{
Yair Listokin, Yale Law School
}

This paper examines the relation between two means of corporate information aggregation-corporate voting and stock market pricing. If the median voter and the price-setting shareholder share similar information, then close proxy contest outcomes should not have systematic effects on stock prices. The paper shows, however, that close dissident victories cause positive movements in stock prices, while close management victories lead to negative price effects. The median voter values management control more than the price-setting shareholder. Voting and market pricing aggregate information in very different ways, with important implications for the role of voting and market pricing in corporate law. (JEL D71, G14, G34, K22, P5)

\section{Introduction}

Corporations have two primary means of aggregating dispersed information and making decisions_- voting and price setting. When shareholders vote on a merger or in a contested director election (two examples of "proxy

I thank Lucian Bebchuk, Alan Gerber, Henry Hansmann, Daniel Ho, Stephanie Listokin, Ian Masias, Roberta Romano, Benjamin Sachs, Alan Schwartz, two anonymous referees, the editor (John Donohue), and seminar participants at Stanford Law School, University of California Berkeley Law School, University of Pennsylvania Law School, the University of Virginia Law School, and Northwestern Law School for extremely helpful comments and discussions and the Oscar M. Ruebhausen Fund for financial support. All errors are my own.

Send correspondence to: Yair Listokin, Associate Professor of Law, Yale Law School, PO Box 208215, New Haven, CT 06520-8215 USA; Telephone: 203-436-2567; Fax: 203-432-4570; E-mail: yair.listokin@yale.edu.

American Law and Economics Review

doi:10.1093/aler/ahp015

Advance Access publication October 23, 2009

(C) The Author 2009. Published by Oxford University Press on behalf of the American Law and Economics Association. All rights reserved. For permissions, please e-mail: journals.permissions@ oxfordjournals.org. 
fights"), they aggregate diffuse opinions through voting; the corporation pursues the outcome favored by the holders of a majority of shares. Given the power of the vote, it is no surprise that Delaware courts describe corporate voting as "fundamental." Corporations also receive feedback from diffuse investors through stock prices. When price-setting shareholders support a company's actions, the price of the company will rise. Indeed, the market's ability to aggregate diffuse information into prices forms the basis for all event studies.

Critics of corporate voting argue that it is a deeply flawed aggregation and decision-making mechanism. The critics say that voting is expensive, unduly favors management, and fails to generate efficient outcomes (Bebchuk, 2005, 2007). Majority voting privileges the median shareholder's opinion over the opinion of other shareholders. Market pricing also has its detractors, with critics arguing that the market focuses on short-term outcomes to an excessive degree, thereby inducing myopic behavior from managers (Lipton and Savitt, 2007).

This paper evaluates these two information aggregation mechanisms from an empirical perspective. More specifically, I estimate how the price-setting shareholder perceives the decisions of the median voter in a corporate election. I do this by examining stock market responses to the announcement of the outcomes of close votes. The stock market response to close votes has two desirable attributes for measuring the price-setting market participant's view of the median voter's opinion. First, the outcome of close votes is uncertain. The announcement of a vote outcome provides information to the price-setting shareholder by resolving this uncertainty. I can evaluate the price-setting shareholder's view of the information by observing the stock market response to the information.

Second, close votes suggest that the median shareholder/voter is nearly indifferent between the two voting options in a proxy contest. The median voter in a proxy contest is the shareholder in the exact middle of a ranking of voters along the dimension of preference for one side (e.g., "existing management") in a proxy contest. If shareholders vote for management so long as they prefer management and the vote is a perfect tie, then the median voter is exactly indifferent between management and "dissidents." If the vote is not a perfect tie but closely favors existing management, then the median voter slightly prefers the winning option, but is relatively "close" to indifference. 
The market response to close votes in proxy voting contests is striking (see Figure 5). In close elections-when the median voter should be nearly indifferent regarding either outcome-the price-setting shareholder is far from indifferent. Stock price responds systematically to the announcement of vote outcomes. When management wins a close election, market value declines; when a dissident wins, the value rises.

I conclude that the price-setting shareholder places lower value upon management control of companies than the median voter. I then examine the implications of this finding for corporate voting and market pricing. I argue that the results either indicate a systematic management advantage in the voting process or a serious flaw in the underpinnings of corporate voting or market pricing. If price-setting shareholders provide a reasonably accurate gauge of value (a proposition that underlies every event study) and value maximization is the goal of corporate law (as most assume) — then the results suggest the need for serious corporate voting reforms.

This paper proceeds as follows. Section 2 discusses existing studies of proxy contests. Section 3 develops a framework for analyzing stock market responses to voting outcomes. Section 4 presents the data and Section 5 empirically examines the stock market response to proxy voting outcomes. Section 6 examines the implications of these findings for assumptions regarding corporate voting and stock market pricing. Section 7 examines possible policy responses and concludes.

\section{Empirical Studies of Proxy Contests}

The impacts of proxy contests on corporate direction and value have been investigated from several perspectives. Pound (1988) examines the probability of winning proxy contests as a function of a number of firm characteristics. For example, widely dispersed shareholders should impede dissidents from mounting and winning proxy contests because dispersion increases the costs of campaigning — costs that are not reimbursed to dissidents whenever dissidents fail to win the contest. Pound's data support this hypothesis; dissident victory rates decline as ownership dispersion rises. Unfortunately, many of the characteristics examined by Pound are endogenous to the probability of winning, casting doubt on Pound's conclusions. For example, shareholder ownership may be more dispersed in firms that are 
less likely to benefit from dissident proxy victories. In this case, dissidents will be less likely to win proxy contests with dispersed share ownership, even if management enjoys no vote-getting advantage.

Other studies (Dodd and Warner, 1983; DeAngelo and DeAngelo, 1989; Ikenberry and Lakonishok, 1993; Mulherin and Poulsen, 1998; Brav et al., 2007) evaluate the stock market responses to proxy contest announcements or the involvement of an activist shareholder (such as hedge funds), finding generally positive effects. Proxy contest announcements, however, may affect value in many ways, such as forcing management to change policies or signaling to the market that informed market participants believe that a firm has potential. As a result, these studies do not provide (nor do they aim to provide) information about the relationship between the information aggregation via corporate voting and information aggregation via market pricing. Similarly, Kamar's (2006) examination of voting on mergers and acquisitions provides evidence on the degree to which companies avoid holding votes. Kamar's study tells little about the relation between value maximization and voting outcomes because management may prefer to avoid proxy votes even though management enjoys systematic advantages in the voting process.

Alexander et al. (2008) (see also Choi et al., 2008) focus on stock market responses to the announcement of proxy advisor recommendations. ${ }^{1}$ They find that a dissident recommendation from ISS - the largest proxy advisor-is associated with a statistically significant increase in market price. While the result is an important one, it again tells little about the relationship between voting and price-setting. When a proxy advisor issues a recommendation, the market receives many pieces of information, including information about the probability of each side winning as well as information about the desirability of each side. A dissident recommendation, for example, "certifies" a dissident as credible. In response, the price-setting market participants may respond positively even if they believe that the company has greater value in the hands of management; the "downside" of a dissident victory in the minds of the market participants is improved by the certification. Therefore, stock market responses to proxy announcements or proxy vote

1. See Alexander, Cindy R., Mark A. Chen, Duane J. Seppi, and Chester S. Spatt's 2008 unpublished paper, "The Role of Advisory Services in Proxy Voting." 
recommendations are not informative about the relationship between the median shareholder/voter and price-setting shareholder.

This paper applies a different methodology-focusing on the outcomes of close votes - to evaluate the impact of vote outcomes on abnormal stock returns. ${ }^{2}$ As explained below, this design addresses many of the critiques of the event study methodology employed by the previous papers.

\section{Median Voters and Price-Setting Shareholders}

As the previous section demonstrated, endogeneity concerns, baseline problems, and data limitations hinder tests of the congruence between voting (and in particular the median voter) and stock market price setting. By combining empirical methodologies, this section attempts to derive such a test.

\subsection{Close Votes and the Median Shareholder Voter}

First, each shareholder/voter, $j$ of a large pool of shares $J$, with rights to vote in a proxy contest receives a signal about the value of the company under incumbent and dissident control, denoted by $V_{I}^{j}$ and $V_{D}^{j} \cdot{ }^{3}$ Let $\Delta^{j}=V_{D}^{j}-V_{I}^{j}$. Assume that a shareholder/voter votes for a dissident if and only if $\Delta^{j} \geq 0$. The median voter, $m \in J$ is the shareholder/voter for whom $\#\left\{j \in J: \Delta^{j} \geq \Delta^{m}\right\} \geq \frac{J}{2}$ and $\#\left\{j \in J: \Delta^{m} \geq \Delta^{j}\right\} \geq \frac{J}{2} .{ }^{4}$ This implies that a tie vote means that $\Delta^{m} \approx 0$; if the median voter prefers incumbents to dissidents, then the median voter, as well as some shareholder voters with $\Delta^{j} \leq \Delta^{m}$ will vote for the incumbents. When this occurs, the assumption that the vote is a tie is contradicted. A symmetric argument applies if the median voter prefers the dissident to the incumbent. Thus, the median voter must be nearly indifferent when the vote is a tie. When

2. Regression discontinuity designs have been applied in finance papers in recent years, for example, Rauh (2006), Roberts and Chava (2007), but they have not been applied to the problem of cross sectional abnormal return regressions such as those described by MacKinlay (1997).

3. Each shareholder may derive these values independently (according to a personalized signal), as in the "Condorcet" voting model, (Young, 1988) or these values may be calculated strategically-each voter may calculate what these values are assuming that they are the decisive vote (Feddersen and Pesendorfer, 1997; Gilson and Schwartz, 2001).

4. The median voter's vote is decisive in a majority voting system. Hence, this paper examines the efficacy of "corporate voting" by focusing on the median shareholder/voter's preferences. 
the number of shareholders is large and the variance of $\Delta^{j}$ is limited, then the median voter will have only a slight preference for one side or the other whenever the vote is nearly a tie.

\subsection{Close Votes and Market Responses}

Assume that there is some set of market participants ("price-setting shareholders") who set prices. ${ }^{5}$ Let $V_{I}^{p s}$ be the price-setting shareholder's valuation of the corporation with an incumbent management victory and let $V_{D}^{p s}$ be the valuation of the corporation when there is a dissident victory. ${ }^{6}$ Suppose that the price-setting shareholder estimates the probability of an incumbent management victory, $\alpha_{I}$. The price set by the price-setting shareholder(s) before the announcement of a vote is $P_{B V}=\alpha_{I} V_{I}^{p s}+\left(1-\alpha_{I}\right) V_{D}^{p s}$ and the price after the announcement of an incumbent management victory is $P_{A V}=V_{I}^{p s}$ and after a dissident victory, the price is $P_{A V}=V_{D}^{p s}$. The market response to the announcement of an incumbent victory, $\Delta P_{I}$, is $P_{A V}-P_{B V}=\left(1-\alpha_{I}\right)\left(V_{I}^{p s}-V_{D}^{p s}\right)$ and the response to a dissident victory, $\Delta P_{D}=P_{A V}-P_{B V}=\alpha_{I}\left(V_{D}^{p s}-V_{I}^{p s}\right)$.

\subsection{Predictions}

This analysis of median shareholder/voters and price-setting shareholders yields several predictions. Prediction 1. If the median voter and the pricesetting shareholder have the same valuations, then there should be no stock price response to the announcement of a tie vote. To see this, recall from Section 3.1 that a tie vote implies that the median voter is nearly indifferent

5. If stock demand is perfectly horizontal, then all shareholders set the price, which equals the present discounted value of earnings of the company. If all participants share common beliefs, however, then this begs the question of why shareholder voting would be split. Consequently, it appears more reasonable to assume differences in shareholder opinion (e.g. Harris and Raviv, 1993). In the Harris and Raviv model (pp. 482-3), one shareholder type constitutes the set of price setting (or marginal) shareholders. "Market pricing" tracks the opinions of this set of shareholders. Thus, evaluation of market pricing is closely related to tracking the preferences of price-setting shareholder. For a similar model emphasizing the role of a price-setting shareholder, see Alexander, Cindy R., Mark A. Chen, Duane J. Seppi, and Chester S. Spatt's 2008 unpublished paper, "The Role of Advisory Services in Proxy Voting."

6. More precisely, $V_{I}^{p s}=\left(V_{I}^{p s} \mid I \succ D\right)$ and $V_{D}^{p s}=\left(V_{D}^{p s} \mid D \succ I\right)$, where $A \succ B$ denotes that option $A$ defeated $B$ in a vote. This reflects the possibility that the pricesetting shareholder uses the vote totals and outcomes to update valuation beliefs about incumbents and dissidents, respectively. 
between management and incumbents, $V_{D}^{m}-V_{I}^{m}=\Delta^{m} \approx 0$. If the pricesetting shareholders have the same valuations of management and incumbents as the median shareholder, then $V_{D}^{p s}-V_{I}^{p s}=V_{D}^{m}-V_{I}^{m}=\Delta^{m} \approx 0$, so $\Delta P_{D} \approx 0$ and $\Delta P_{I} \approx 0$. Analogously, close votes-those that are near ties-should have relatively mild stock price responses when the median voter and the price-setting shareholder have similar or identical valuations. ${ }^{7}$

Now, suppose that the valuations of the median voter have no relation to the valuations of the price-setting shareholder. Under these assumptions, the magnitude of the stock market response to a vote outcome depends upon the price-setting shareholder's view of the likelihood of that outcome occurring. Thus, $\Delta P_{D} \propto \alpha_{I}$, the more the price-setting shareholder expects incumbents to win, the greater the stock price response to a dissident victory and the lower the response to an incumbent victory. Moreover, the dispersion of price responses should be the highest where $\alpha_{I} \approx 0.5$. $^{8}$

Prediction 2. If price-setting shareholder valuations are not equivalent to median voter valuations and the set of close votes has a large intersection with the set of votes where $\alpha_{I} \approx 0.5$, then the magnitude of stock price responses to close votes should be larger than the responses to other votes.

It should be emphasized, however, that $\alpha_{I}$ for the price-setting shareholder is not observable. While a rational price-setting shareholder will presumably have the most uncertainty when the observed vote is close, so that there is considerable overlap between the set of close votes and the set of votes for which $\alpha_{I} \approx 0.5$, this overlap is not guaranteed. At times, the price-setting shareholder will expect a close vote $\left(\alpha_{I} \approx 0.5\right)$ but the eventual vote outcome will not be close-management's share of the vote will be considerably greater or less than $50 \%$. In these circumstances, there may be a large stock price response to a vote that is not as close as the price-setting shareholders' expectation. Alternatively, some votes that are actually close may not have been expected to be close $-\alpha_{I}$ is not near 0.5 . These votes will be close but will not always result in large price responses. Under these

7. If the median voter and price-setting shareholder have the same valuation and the price-setting shareholder knows this, then the price-setting shareholder will know the outcome of the vote before it is announced. I therefore assume that price-setting shareholders have some uncertainty about the valuation of the median voter.

8. The stock price response is a binomial random variable that can take value $\Delta P_{D}$ with probability $\alpha_{I}$ and value $-\Delta P_{D}$ with probability $1-\alpha_{I}$. The variance of a binomial is proportional to $\alpha_{I}\left(1-\alpha_{I}\right)$, which is highest where $\alpha_{I}=0.5$. 
conditions, the average close vote will have a larger stock price response that is more informative about the price-setting shareholders valuation, $\left(V_{D}^{p s}-V_{I}^{p s}\right.$ ), than the average lopsided vote. Some (unexpectedly) lopsided votes will have strong price reactions, however, while some (unexpectedly) close votes will have small reactions even if $\left(V_{D}^{p s}-V_{I}^{p s}\right)$ is significantly different from zero. Thus, Prediction 2-that stock price responses should be largest to close votes - should be true on average rather than in all cases.

Another complication to this framework concerns the results of Listokin (2008). That paper discovered that management frequently wins a vote on a management-sponsored proposal by a close margin, but seldom loses by a similarly narrow amount. The price-setting shareholder may therefore expect management to win a disproportionate number of close votes. As a result, votes decided by narrow margins are not viewed as toss-ups $\left(\alpha_{I} \approx 0.5\right)$ by the price-setting shareholder, but rather as contests likely to go management's way $\left(\alpha_{I}>0.5\right)$. Under these assumptions, Prediction 3a will hold - the magnitude of stock market responses to close elections should be asymmetrical. For a given $\left(V_{D}^{p s}-V_{I}^{p s}\right)$, narrow dissident victories, which are unexpected, should have a larger stock market response than narrow management victories, which are more expected. $\left|\Delta P_{D}\right|=\alpha_{I}\left(V_{D}^{p s}-V_{I}^{p s}\right)>\left|\Delta P_{I}\right|=\left(1-\alpha_{I}\right)\left(V_{I}^{p s}-V_{D}^{p s}\right)$ for a fixed $\left(V_{D}^{p s}-V_{I}^{p s}\right.$ ) when $\alpha_{I}>0.5$. Moreover, (Prediction 3b), the asymmetry in responses to management and dissident victories should be particularly large for votes that are close but not extremely close; when a dissident wins by a relatively wide margin, it may contain considerable new information for the market, since price-setting shareholders, knowing that management is likely to win the close ones, will only expect an outcome toss-up ( $\alpha_{I} \approx$ 0.5 ) when the dissidents have a voting support advantage that offsets management's advantage in close votes.

All of these predictions will be examined empirically in the following sections.

\section{Proxy Voting Data and Summary Statistics}

\subsection{Data and Summary Statistics}

Georgeson Shareholder's list of proxy contests in its Annual Corporate Governance Report from the years 2000 through 2006 constitutes the starting 
point for my data collection. For each proxy contest listed by Georgeson that was decided by vote, ${ }^{9}$ I collect voting data - the date of a vote as well as votes received by both management and dissidents-from each company's public filings, most commonly a $10-\mathrm{Q}$ or 8 -K filing for the appropriate time period. This data were combined with stock market data from CRSP, supplemented by data from Yahoo! Finance for three stocks traded on the pink sheets markets. ${ }^{10}$ The sample includes all companies in the Georgeson reports with available stock market data and voting data.

There are ninety-seven contested proxy votes in the sample. The year 2001 witnessed the greatest number of votes (twenty-two), while 2005 had the fewest (seven). Eight of the proxy votes concerned merger approvals (a tiny fraction of total U.S. mergers and acquisitions activity) and seventy-four concerned director elections (again, a tiny fraction of the number of director elections over the period). The remaining fifteen contests concerned assorted topics such as confidential voting or the adoption of cumulative voting, with no issue being the subject of more than three votes. Dissidents won thirtyseven of the ninety-seven proxy votes, for a success rate of $38 \%$.

The average market value for the companies in the sample is approximately $\$ 1.47$ billion, while the median market value is $\$ 130$ million-the average is raised by the presence of several companies worth over $\$ 10$ billion. The tenth percentile of market value is roughly $\$ 30$ million.

Most proxy contests are competitive. ${ }^{11}$ Figure 1 presents a histogram of the percentage of votes received by management in the proxy contests. Management receives an average of only 53\% of the necessary vote in proxy contests and over half of the contests were decided by margins of under twenty percentage points. This competitiveness is not surprising; because dissidents must expend their own funds on proxy contests, it makes little sense to commence a proxy contest with little chance of winning.

9. A number of proxy contests climax in a settlement between the dissident and management. Because the outcome of these settlements is hard to characterize both practically and chronologically, these observations are excluded from the analysis. In addition, some contests concern more than one issue. For these contests, I focused on the issue that would have the greatest consequences for the company, such as a contested director election rather than a new bonus plan for management.

10. Excluding the pink sheets stocks does not substantively affect the estimates presented below.

11. This starkly contrasts with votes on management-sponsored proposals, which are overwhelmingly lopsided. See Listokin (2008). 


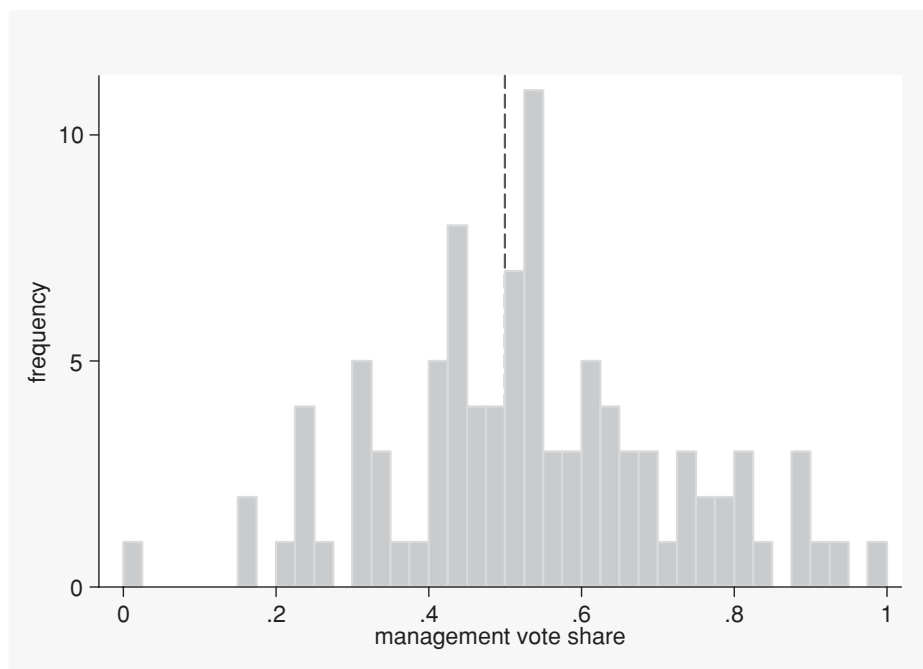

Figure 1. Management Votes Shares for Proxy Contests Listed in Georgeson Shareholder's Annual Corporate Governance Report of 2000-2006. The figure reports results for all proxy contests that went to a vote and for which data were available from SEC filings. This data are the vote share data used in all future figures and tables.

In addition, most proxy contests involve high turnout as a percentage of total shares outstanding. In the median contest in the sample, over $78 \%$ of shares were voted. As a result, it is unlikely that close results are caused by indifference, such as when management gets to a threshold that it knows it needs and stops accumulating votes. ${ }^{12}$

The appropriate calculation of vote percentage presents a complication. While the number of votes in favor of management is clear (the percentage's numerator), the denominator used to calculate the percentage varies by issue based on state default law and corporate charter amendments. For example, an agreement to be acquired by or merge with another company must be supported by $50 \%$ of shares outstanding, ${ }^{13}$ while approval of the acquisition of a smaller company (when such approval is required) generally

12. Listokin (2008) demonstrates that arriving at a vote threshold and stopping is quite unusual even when there is not high turnout.

13. 8 Del. C. $\S 251$ (c), $\S 271$ (a). (In the contested merger contests (which are most likely to have deviations from state default law) the requisite percentage was verified. 
needs only $50 \%$ of votes cast. ${ }^{14}$ Directors are elected by plurality rules. ${ }^{15}$ Throughout the paper, the denominator applied to calculate the percentage of votes received by management depends on the requirement for management success. To illustrate, consider a company with 1000 shares. At an annual meeting following a proxy contest, 450 votes are cast in management's favor on some issue while 350 votes are cast against. If the issue is approval of a merger, management failed to gain approval, since it needs a majority of shares outstanding (at least 501 votes). In Figure 1 (and all other figures and regressions), management's vote percentage is therefore presented as $45 \%=450 / 1000$. If the issue is a director election, however, then management's slate will have won, as it has received over $56 \%=450 / 800$ of votes cast. This outcome will be presented as management receiving $56.25 \%$ in Figure 1 and other figures.

Figure 1 also relates to previous research on management's ability to disproportionately succeed in close elections. Listokin (2008) demonstrated that management wins very close corporate votes (those decided by margins of no more than 10\%) far more often than management loses. Figure 1 similarly demonstrates a disproportionate management win rate (eighteen wins in twenty-six chances) in proxy contest voting. If we assume that management wins and losses in close votes (votes where management receives more than $40 \%$ but less than $60 \%$ of the votes) are truly toss-ups that should be binomially distributed (Gerber and Malhotra, 2008), then a distribution as favorable to management as the one observed in Figure 1 should occur randomly less than $4 \%$ of the time. ${ }^{16}$

The disproportionate management win rate observed in Figure 1 is less pronounced than the management win rate observed in Listokin (2008). The discrepancy in management win rates between Figure 1 and Listokin (2008) is likely related to differences between the two samples of votes under study. Listokin (2008) examines votes on all management proposals. Many such proposals have one-sided proxy solicitation-by management

14. 8 Del. C. $\S 216(2)$.

15. 8 Del. C. $\S 216(3)$.

16. Defining votes between $40 \%$ and $60 \%$ as toss-ups is arbitrary, of course. If we restrict the characterization of toss-ups to votes between $45 \%$ and $55 \%$, then the probability of randomly obtaining the management win rate observed in Figure 1 becomes 27\%. Small sample sizes prevent a conclusive determination that management disproportionately wins the close votes examined in this paper. 
but not by opponents of management's proposal. In the disputed proxy contests examined in Figure 1 and the remainder of the paper, however, the dissidents are sufficiently invested to incur the expense of a proxy contest and may well have hired their own solicitors for last minute lobbying. This may reduce, but does not appear to eliminate, management's advantage in close votes.

\subsection{Empirical Methodology}

As developed in the theoretical section, the market response to close election outcomes yields important information about the relative valuations of median voter and price-setting shareholders with respect to management control versus dissident control. Instead of running a standard event study that suffers from the flaws described in Section 2, I apply a regression discontinuity (RD) design (Imbens and Lemieux, 2007). ${ }^{17}$ This constitutes a variant of the "cross sectional" abnormal return methodology (MacKinlay, 1997), in much the same way that RD generally constitutes a variant of standard cross-sectional regression. Regression discontinuity analysis seeks to uncover the causal effect of assigning a particular treatment (in this case, a dissident victory) on an outcome (in this case, firm value). The RD design assumes that expectations of victory and other company characteristics are similar on average for companies that receive similar levels of voting support. ${ }^{18}$ For example, companies in which management receives $49.9 \%$ of the vote should be similar (in terms of both expected vote outcomes and company characteristics) to companies in which management receives $50.1 \%$ of the vote. While $49.9 \%$ companies may be similar in many dimensions to $50.1 \%$ companies, they differ in the treatment they receive. The $49.9 \%$ companies receive the dissident treatment while the $50.1 \%$ companies receive the management treatment. ${ }^{19}$ Regression discontinuity examines the

17. Note that Table 2 presents regression results that follow a more standard event study methodology, with very little change in results.

18. The RD design thus is not affected by correlation between firm characteristics and the degree of anticipation of an event, a concern for other variants of cross-sectional abnormal return methodology (Prabhala, 1997).

19. The RD design also mitigates "selection" concerns arising from the fact that companies that have votes on proxy contests are different from companies that settle proxy contests and very different from average companies. While there may be enormous differences between companies with contested proxy votes and other companies, the 
changes in value for the two groups and asserts that differences in value are the causal effect of management control versus dissident control.

Some evidence about the validity of the RD assumption is given in Figure 2. If companies that narrowly win and lose votes are relatively similar, the distribution of firm characteristics between the two groups of companies should be similar. Figure 2 shows that companies that narrowly win and narrowly lose proxy votes are of similar size, have similar institutional ownership percentages, and have relatively similar insider ownership shares, ${ }^{20}$ with no systematic discontinuities evident at vote shares around 0.5. Discontinuities around a vote share of 0.5 are also absent from noncontinuous variables, such as the exchange on which companies are traded and their industry.

McCrary (2007) explains that manipulation of the "running variable" (in this case, management's vote share) precludes simple causal inferences in RD designs. Figure 1 demonstrates that manipulation of the vote share is a possibility, as there are more close management victories than close dissident victories. As a result, the RD estimates presented below cannot be interpreted as providing a causal estimate of the impact of a dissident victory on value. Instead, the RD estimates should be interpreted as an estimate of the price-setting shareholder's relative valuation of management versus dissident control when the median voter is nearly indifferent between the two sides, regardless of whether or not the median voter's opinion has been influenced in a nonrandom fashion. ${ }^{21}$

$\mathrm{RD}$ designs present results both graphically and analytically (Imbens and Lemieux, 2007). The impact of management victory on the market price is estimated by

$$
\tau=\lim _{v \rightarrow 50+} E[Y \mid v=50]-\lim _{v \rightarrow 50-} E[Y \mid v=50]
$$

difference between companies that both have votes where management receives similar vote shares should be much smaller. The RD design identifies the impact of control from small variations in votes received. It should be emphasized, however, that the results presented below constitute local average treatment effects (LATE) estimates for companies engaged in close proxy contests, rather than randomly selected companies (Imbens, 2007).

20. One of the narrow management victories had an extremely high insider ownership share.

21. Because the median voter is decisive in corporate majority voting, the median voter's indifference is relevant regardless of how that indifference is caused. 
a

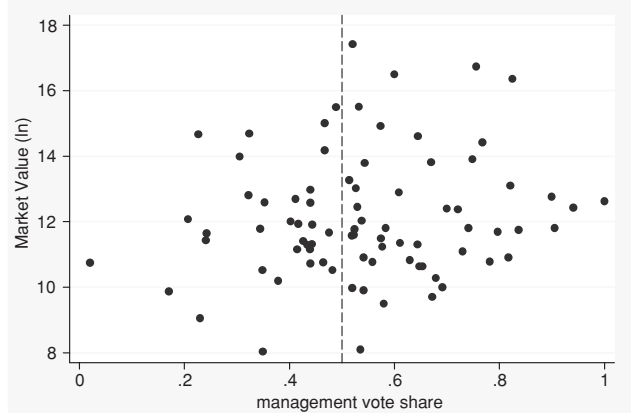

b

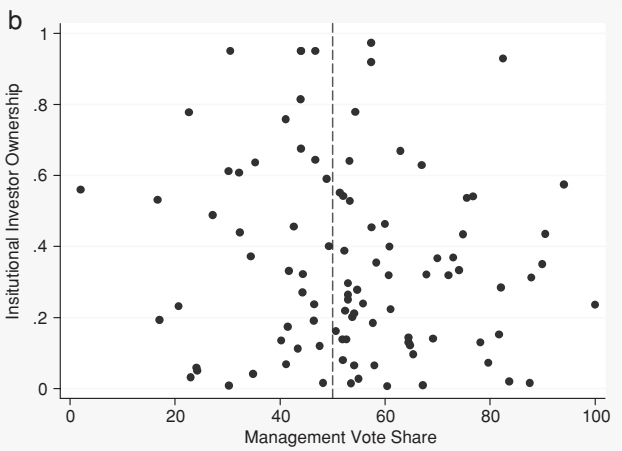

C

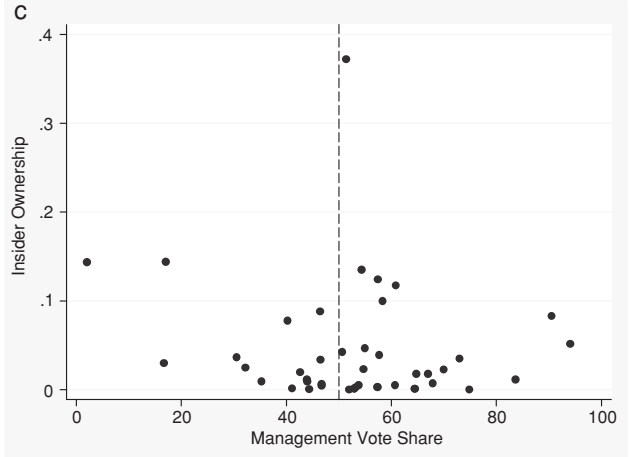

Figure 2. (a) Market Values Calculated from CRSP Data on Shares Outstanding and Market Price. For "pink sheets firms" (a total of three), data were obtained from Yahoo! Finance. All the remaining figures and tables use this market value data. (b) Prevote Institutional Ownership and Management Vote Share. Institutional ownership data on companies with contested proxy votes collected from Bloomberg Data Services. (c) Prevote Insider Ownership and Management Vote Share. Insider ownership data for firms with contested proxy votes collected from Bloomberg data services. 
where $v$ is management's vote share and $Y$ is the change in market value. These limits (and therefore $\tau$ ) are estimated using a kernel regression design with an Epanechnikov kernel approaching vote shares of fifty. Separate kernel regressions are run when approaching a share of fifty from above and below (Imbens, 2007). ${ }^{22}$ Standard errors for $\tau$ are estimated via bootstrapping.

Several methodological questions remain. First, the "event" date on which news of a proxy vote outcome is available to the market is ambiguous. The study uses the day of a vote as the event date. This may not be accurate. While most voting outcome announcements found in simple Internet searching are announced on the day of the vote (the polls typically close in the morning of the day of the annual meeting), some votes are announced after the day of the vote. As a result, I use three-day abnormal returns to capture events that are not incorporated into stock prices on the day of the vote. If the event windows do not capture proxy outcome news, the study is biased toward not finding any significant effects.

Second, different proxy issues are also likely to have different stock price responses. Some of the proxy contests described in the Georgeson publications concern issues that have ambiguous implications for stock market value, such as bylaw amendments or advisory votes. To focus on issues that are likely to be important for value, the empirical analysis presented below examines votes concerning contested mergers and contested director elections. These contests are examined separately and as a single sample.

\section{Stock Price Responses to Proxy Voting Outcomes}

Table 1 and Figure 3 present stock market responses to contested proxy voting outcomes about mergers and acquisitions. Merger proxy contests are likely to be the extremely significant for corporate value. The results are

22. The Epanechnikov kernel weighting places greater weight on an observation the closer it is to fifty. The weights go down in quadratic fashion as an observation's vote share diverges from fifty. Because the number of observations is limited, bandwidth sizes are larger than they would be if data were more plentiful. Smaller bandwidth sizes typically have almost no impact on point estimates, but raise standard errors. Bandwidth and kernel shapes for local regressions are included in all tables. Standard event studies can be viewed as a special case of regression discontinuities with infinite bandwidth and a rectangular kernel. 
Table 1. Stock Price Responses to News of Proxy Contest Outcomes

\begin{tabular}{lccc}
\hline & Merger Votes & Director Elections & $\begin{array}{c}\text { Merger and } \\
\text { Director Votes }\end{array}$ \\
\hline $\begin{array}{l}\tau(\text { Limit of change in market } \\
\text { value when management }\end{array}$ & $-0.083^{*}(0.047)$ & $-0.059^{*}(0.031)$ & $-0.069^{* *}(0.029)$ \\
$\quad$ & & & \\
wins minus change in value & & & \\
when management loses $)$ & Epanechnikov & Epanechnikov & Epanechnikov \\
Kernel & 20 & 5 & 5 \\
Bandwidth & 47.9 & 54.9 & 54.2 \\
Average Management Vote & & & 82 \\
$\quad$ Share\% & 8 & 74 & \\
Number of Observations & & & \\
\hline
\end{tabular}

Notes: Standard errors are in parentheses.

${ }^{* * *} P<0.01,{ }^{* *} P<0.05,{ }^{*} P<0.1$.

$\mathrm{RD}$ estimates of differences in value between management and dissident victory as the vote share approaches $50 \%$. The number of votes necessary to win each vote differs. Target votes on acquisitions generally require supermajorities (e.g., two-thirds of votes shares outstanding or majority of shares outstanding). Acquirer votes on acquisitions require a simple majority of votes cast. See, for example, NYSE Listed Company Manual, Sections $312.03,312.07$. The All votes cast estimates use normalized vote shares where the vote share is compared to the number necessary for management to win. Bandwidths are chosen to balance bias versus variance. The more observations, the smaller the bandwidth. See Deaton (1997) for details. Generally, smaller bandwidths have a small impact on the point estimates (leaving them unchanged or raising them slightly, but raise standard errors).

striking. Dissident victories under study were not overwhelming victories; management received almost $50 \%$ of votes cast in these votes. ${ }^{23}$ Therefore the vote outcomes were likely both informative and controversial. The kernel regression estimates that a management victory leads to an $8.3 \%$ decrease in value, a result that is statistically significant at the $10 \%$ level in spite of the paucity of observations. Moreover, the result is not the artifact of one extreme case. The smallest positive abnormal return associated with a dissident victory was over $4 \%$. Management victories, by contrast, are associated with zero to slightly negative abnormal returns.

Table 1 and Figure 4 present a similar but less pronounced story with respect to director election proxy contests. The RD design estimates $\tau$ - the difference between management and dissident victories in the limit approaching $50 \%$-as approximately $-6.0 \%$, an estimate that is significant at the $10 \%$ level. Figure 4 presents further graphical evidence that dissident victories are associated with increases (some of which are quite large) in stock market value while narrow management victories lead to decreases in value.

23. Management lost the votes because they did not obtain a majority (or in one case a supermajority) of the votes of shares outstanding. 


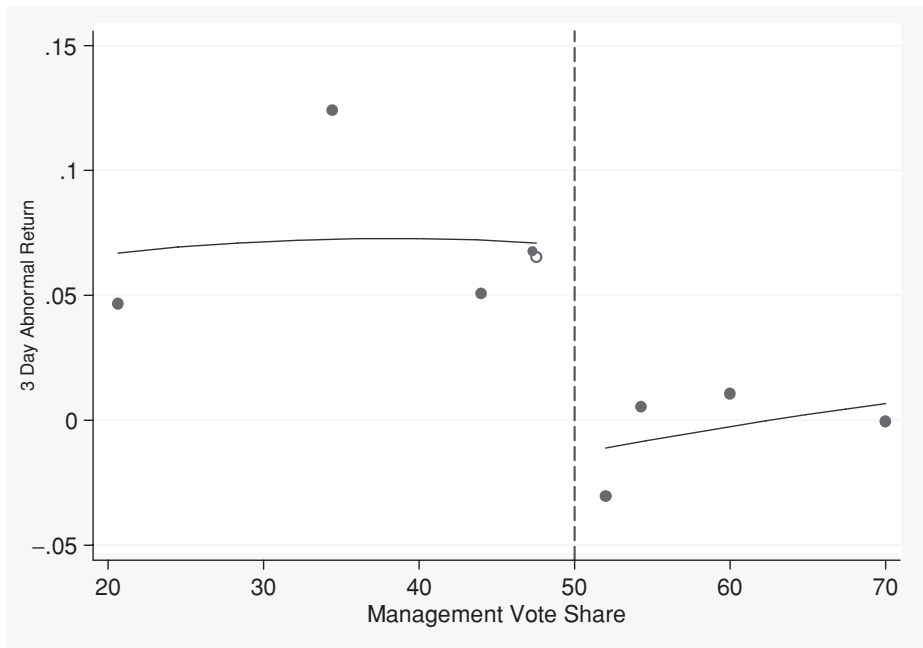

Figure 3. Stock Market Responses to Proxy Contest Outcomes Regarding Mergers. Abnormal return calculated according to standard event study methodology (MacKinlay, 1997) using a market model of returns. Management vote share is calculated relative to the appropriate denominator for each corporation. If a proposal must receive a majority of shares outstanding to win, then the management vote share is calculated relative to the number of shares outstanding. The management vote share in these cases is therefore lower than it would be if it were calculated as a proportion of votes cast. Each scatter point represents a particular proxy vote and the subsequent abnormal return for the company's stock. Each line is a kernel regression using an Epanechnikov kernel and a bandwidth of twenty.

Table 1 (column III) and Figure 5 combine director and merger votes in one specification. The RD design provides an estimate of $\tau$ of $-6.9 \%$. This result is statistically significant at the 5\% level. Moreover, it is quantitatively significant, suggesting that price-setting shareholders place considerably higher value on dissident victories than on management victories.

The previous RD estimates used bandwidths that placed little weight on observations that did not have extremely close votes. The theoretical analysis presented above, however, provided several reasons to suspect that stock price responses to more lopsided votes will also contain information about the price-setting shareholder's relative valuations of dissident and management victories. Table 2 presents the results of a regression of threeday cumulative abnormal returns on a dissident victory dummy variable for 


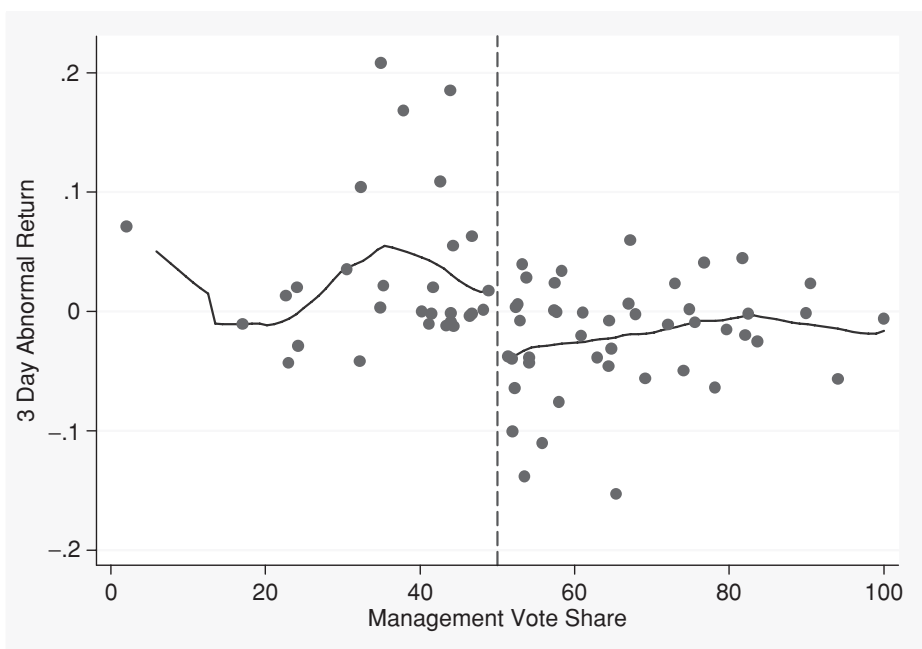

Figure 4. Stock Market Responses to Proxy Contest Outcomes Regarding Director Elections. Management vote share is calculated relative to votes cast. Each scatter point represents a particular director election and the subsequent abnormal return for the company's stock. Each "line" is constructed via a kernel regression using an Epanechnikov kernel and a bandwidth of five.

the sample of merger and director votes where the winning side received less than $70 \%$ support compared to the relevant voting population. ${ }^{24}$ The results support the estimates of Table 1. Dissident victories in these somewhat closely contested contests are associated with an approximately 7\% increase in stock market value relative to management victories. This result is statistically significant at the $1 \%$ level and provides further support for the notion that price-setting shareholders value dissident victories as $5-7 \%$ more valuable in votes where the outcome is uncertain.

To examine whether this pattern persists over longer periods, Table 2 (columns 3 and 4) also presents the results of a regression of one-year cumulative abnormal returns on a dissident victory dummy variable for the

24. The specifications in Table 2 therefore constitute "cross-sectional abnormal return regressions"- a variant of the standard event study methodology—as described in MacKinlay (1997). The cross-section in Table 2 is limited to relatively close votes (where the winning side receives less than $70 \%$ of the required voting population). All votes meeting these criterion are weighted equally. 


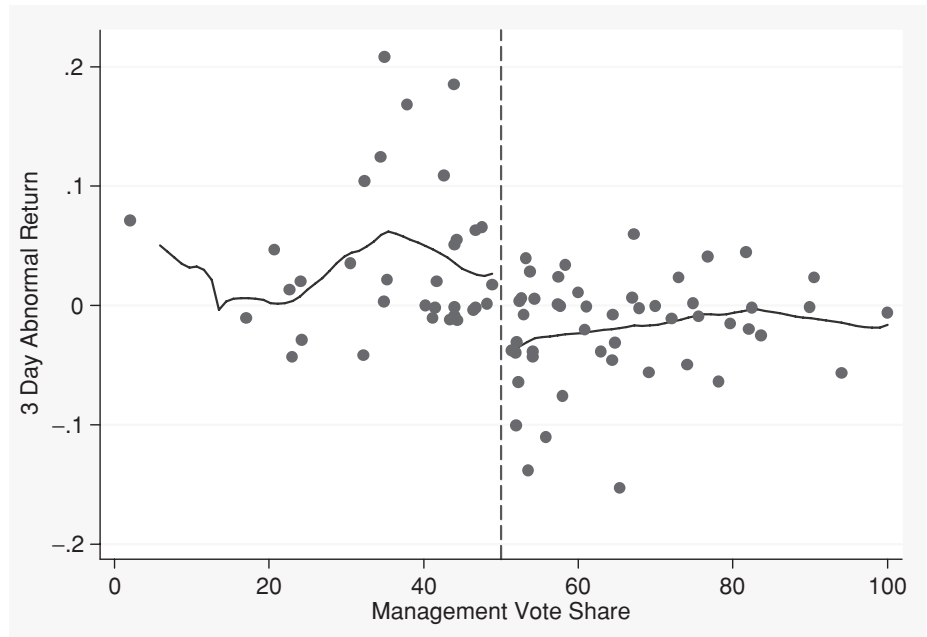

Figure 5. Stock Market Responses to Merger and Director Election Proxy Contests. Management vote share is calculated relative to the relevant voting population. Each scatter point represents a particular vote and the subsequent abnormal return for the company's stock. Each "line" is constructed via a kernel regression using an Epanechnikov kernel and a bandwidth of five.

sample of merger and director votes where the winning side received less than $70 \%$ support compared to the relevant voting population. The results are inconclusive, as might be expected given the small sample size and wide dispersion of abnormal returns over a one-year period. One-year abnormal returns are positively correlated with dissident victories, though in ordinary regressions (column 3) the impact of dissident victories is both smaller in size $(1.4 \%)$ and nowhere near statistical significance. Because the regression in column 3 may be driven by outliers, column 4 presents a quantile regression (at the median), which places less weight on outliers. In this regression, a dissident victory has an estimated positive $7.8 \%$ impact on value, which is consistent with the short-run estimates. Again, however, standard errors are so large that the result is not statistically significant.

Figures 6 and 7 demonstrate that (with one or two exceptions) the change in market values associated with close wins and close losses are generally not caused by large changes in the net positions held by institutions or insiders (data on insider and institutional ownership come from Bloomberg). 
Table 2. Regression Results: Cumulative Abnormal Returns as a Function of Dissident Victories in Relatively Closely Contested Contests

\begin{tabular}{lccc}
\hline COEFFICIENT & $\begin{array}{c}3 \text { day } \\
\text { abnormal return } \\
(1)\end{array}$ & $\begin{array}{c}\text { One-year } \\
\text { abnormal return } \\
(2)\end{array}$ & $\begin{array}{c}\text { One-year } \\
\text { abnormal return, } \\
\text { median regression } \\
(4)\end{array}$ \\
\hline Dissident Victory & $0.0712^{* * *}$ & 0.0139 & 0.0786 \\
Constant & $(0.0153)$ & $(0.115)$ & $(0.105)$ \\
& $-0.0252^{* *}$ & 0.0488 & 0.00669 \\
Observations & $(0.0100)$ & $(0.0743)$ & $(0.0683)$ \\
$R$-squared & 58 & 55 & 55 \\
\hline
\end{tabular}

Standard errors in parentheses.

${ }^{* * *} P<0.01,{ }^{* *} P<0.05,{ }^{*} P<0.1$.

The sample examined in this table concerns all votes regarding mergers and directors where the winning side received less than $70 \%$ of the relevant vote population. (All other tables and figures use all votes-even if they are lopsided.) Column 2 presents results from a regression of three-day cumulative abnormal returns (the dependent variable) on whether or not dissidents won the vote. Column 3 presents results from a regression of one-year cumulative abnormal returns on whether or not dissidents won the vote. Because the results in column 3 may be driven by outliers, column 4 presents quantile regression results (at the 50th percentile) for one-year abnormal returns. All observations in each regression are weighted equally.

Institutional holdings of corporate shares generally rise regardless of whether management or dissidents win the vote. Insider holdings also stay relatively constant, although there are some cases of insider holdings rising considerably after a decisive dissident victory. ${ }^{25}$

\section{Prediction Testing}

The theoretical framework developed in Section 3 made several differing predictions regarding the stock market price response to close proxy contests. The differing predictions stemmed from different assumptions regarding the nature of shareholder voting and market price setting. If a prediction proves false then this provides strong evidence that the assumptions behind the prediction are incorrect. ${ }^{26}$ If a prediction holds true, then this provides

25. One explanation for insider holdings rising after decisive management losses is that the identity of the insider has changed, perhaps because large shareholders have retaken direct control of a company from management.

26. Falsehood of the prediction proves falsehood of the assumptions via the contrapositive result. 


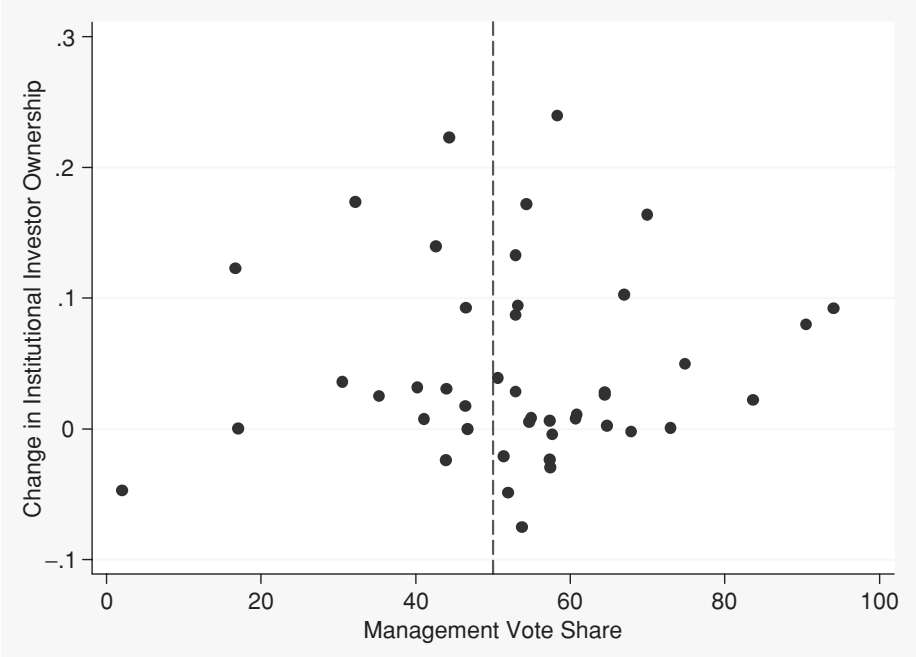

Figure 6. Change in Institutional Ownership Share and Management Vote Shares. The change in institutional investor ownership is calculated by subtracting the institutional ownership share in the quarter before the vote from the institutional ownership share in the quarter after the vote.

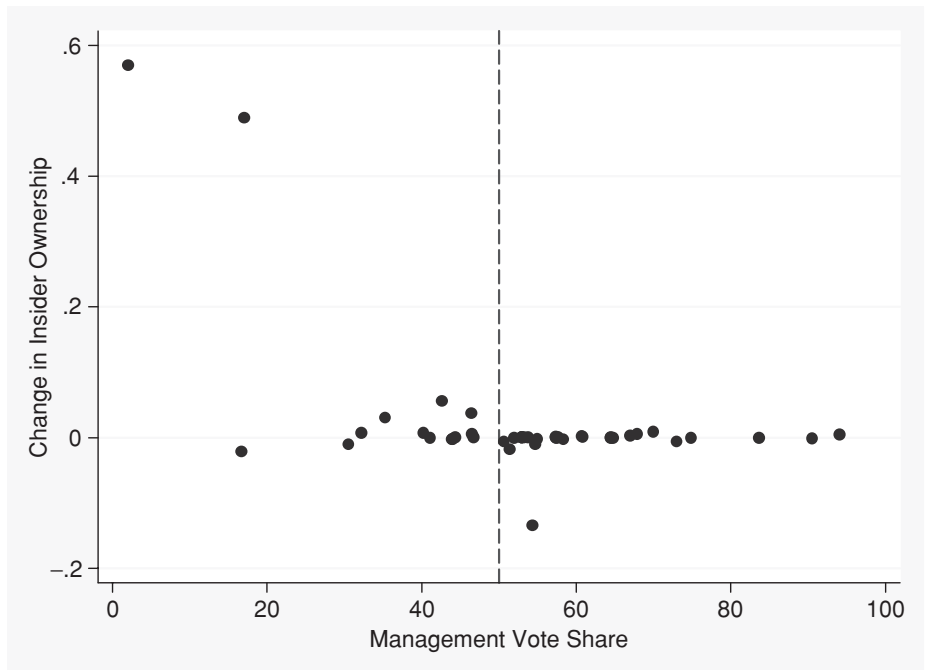

Figure 7. Change in Insider Ownership Share and Management Vote Share. The change in insider ownership is calculated by subtracting the insider ownership share in the quarter before the vote from the insider ownership share in the quarter after the vote. 
evidence, but not conclusive evidence, that the assumptions behind it are true. This Section reviews the performance of the various predictions.

Prediction 1. If the median voter and the price-setting shareholder have the same valuations, then there should be a small stock price response to the announcement of the outcome of a close vote. This prediction fares extremely poorly. As Figures 3-5 demonstrate, close votes are often associated with large stock price movements in excess of $10 \%$ of the value of the company. These findings suggest that the median voter and the pricesetting shareholder frequently do not have similar valuations for dissident and management control. When the median shareholder is nearly indifferent between dissidents and management, the price-setting shareholder often demonstrates a marked preference for one side versus the other. Moreover, these differences are not random; the median shareholder values management control more than the price-setting shareholder values management control. When the median shareholder is nearly indifferent, the price-setting shareholder generally values dissident control as 5-8\% more valuable than management control (see Tables 1, 2 and Figures 3-6).

Prediction 2. If price-setting shareholder valuations are not equivalent to median voter valuations and the set of close votes has a large intersection with the set of votes where $\alpha_{I} \approx 0.5$, then typical stock price responses to close votes should be larger than the responses to other votes. Having already demonstrated that price-setting shareholder valuations are not equivalent to median voter valuations, the performance of this prediction yields information about whether the set of close votes is similar to the set of votes where $\alpha_{I} \approx 0.5$. Figures $3-5$ indicate a significant overlap between these two set of votes. Stock market responses generally have the highest magnitude in close votes, with the response trending toward zero as the vote gets progressively more lopsided. This pattern is far from absolute, however. There are many votes that are decided by reasonably large margins that witness large stock market reactions. For example, votes where the winning side gets between $60 \%$ and $70 \%$ of the vote have stock market responses that are just as large as votes where the winning side gets less than $60 \%$. The most accurate characterization of the data is that extremely lopsided votes are expected and have small stock responses, while votes where the winning side receives less than $70 \%$ often have large stock responses. The average absolute value of the abnormal return is approximately $1.7 \%$ higher 
for votes where the winning share receives less than $70 \%$ compared to votes where the winning share exceeds $70 \%$.

There are two explanations for the imperfect relationship between the set of close votes and the set of votes with large stock responses. First, it may be difficult for shareholders to perfectly prognosticate which votes will be close. Some votes that were expected to be close will not be, while other votes will be closer than expected. This effect will cause some dispersion in the set of votes that have large market responses. Second, if management has an advantage in close votes, then the set of votes for which $\alpha_{I} \approx 0.5$ will differ from the set of close votes. Some convincing dissident victories may provide considerable information to the market, because the price-setting shareholder assumed that a close vote would be won by management.

Prediction 3a. The magnitude of stock market responses to close elections should be asymmetrical.

Prediction 3b. The asymmetry in responses to management and dissident victories should be particularly large for votes that are close but not extremely close.

If management has an advantage in close votes, then the set of votes for which $\alpha_{I} \approx 0.5$ may correspond to cases where management receives an average voting support of less than $50 \%$, leading to relatively large stock responses to seemingly decisive dissident victories. Prediction $3 \mathrm{a}$ and $3 \mathrm{~b}$ both receive some support in the data. For votes where the winning side received less than $70 \%$ of the vote, dissident victories had an abnormal return that was $1.5 \%$ greater in magnitude than management victories, supporting prediction $3 \mathrm{a}$-although the difference is not statistically significant. The asymmetry between stock price responses for votes that are close but not extremely close (the winning side received more than $60 \%$ but less than $70 \%$ ) is even larger. Dissident victories in this range have stock price response magnitudes that are over 5\% larger than management victories between $60 \%$ and $70 \%$, supporting prediction $3 b$.

\section{Conclusion}

The results just presented are consistent with, though they do not prove, several critiques of the corporate voting process. Critics of voting in proxy contests argue that management enjoys many advantages over dissidents 
including: (i) discretion over the timing of a vote (which is set by management); (ii) relationships and contact information for shareholders (dissidents may have to sue to obtain a list of shareholders, while management has been in contact with shareholders for an extended period); (iii) unlimited funds from corporate coffers for soliciting proxies (dissidents are only reimbursed for proxy expenses when they defeat management); and (iv) the ability to use financial leverage to influence the vote of institutional shareholder (management may threaten to withhold business from financial institutions that vote against them). (Bebchuk, 2007, pp. 688-93). Bebchuk adduces the small total number of dissident proxy campaigns as empirical evidence of management's systematic advantage, but critics (e.g., Macey, 2007) correctly observe that Bebchuk has no baseline for the "correct" number of proxy fights. The evidence presented here, by contrast, offers information aggregation via stock market price setting as a baseline for evaluating the efficacy of voting.

If management's campaign advantages alter the opinion of the median shareholder but have no (or less) impact on the price-setting shareholder, then the results observed here should follow. Suppose that the median shareholder and the price-setting shareholder originally share the same opinion, but that management's advantages are able to "move" the opinion of the median shareholder in favor of management. (In other words, suppose that management has a built-in block of votes of a certain percentage). Thus, a very close shareholder vote means that, absent campaign effects, the median shareholder preferred the dissident group. The price-setting shareholder, who by assumption is unmoved by campaign effects, therefore places greater value on dissident control than on management control whenever the median voter is indifferent. ${ }^{27}$ This explains why narrow dissident victories raise market value, while narrow management wins reduce value. ${ }^{28}$

27. Even if most of the votes in play in a contested election are voted by hedge funds that vote to maximize price, different hedge funds may have different opinions about the direction of the price. With a built-in advantage, management needs to convince fewer hedge funds and institutions to vote its way. In this case, it is possible that the median institutional voter votes to maximize value, but that the median institutional voter is different from the median shareholder voter.

28. The results are also consistent with models of "insincere voting" in corporate law. That is, voting behavior that differs from an individual shareholder's private signal about the merits of management vs. dissidents. See, for example, Gilson and Schwartz (2001), 
Alternatively, some have argued that "empty voting" or decoupling in corporate elections may adulterate the quality of voting (Martin and Partnoy, 2005; Hu and Black, 2006). Empty voting occurs when shareholders hold votes without corresponding economic interests. To this point, however, the extent of empty voting is unknown. The results presented here are consistent with empty voting. One symptom of empty voting would be a divergence between the interests of the median voter and price-setting shareholder. Note, however, that the results presented above are only consistent with a peculiar form of empty voting in which management takes greater advantage of the empty voting process than dissidents. To this point, no commentators have suggested why there might be such an asymmetry.

If either of these interpretations (management advantage or empty voting) of the data is correct, then several conclusions follow. Shareholder voting needs reform if its aim is to maximize shareholder value, which is voting's purpose according to Easterbrook and Fischel (1983). Reforms need to equilibrate proxy campaigns so that management cannot unduly influence shareholder votes. Several reforms, such as dissident proxy financing, shareholder access to the corporate ballot, and fixed director election dates, will reduce some of management's unique campaign-related advantages that may allow voting outcomes to diverge from value.

This interpretation of the results is plausible, but far from necessary. It assumes, as do all studies related to the event study methodology, that the market information aggregation mechanism (with price set by the "pricesetting shareholder") values companies accurately. This need not be the case. Instead, corporate voting, using the median shareholder voter's information set to make decisions, may aggregate information more efficiently than the price setting mechanism. In this case, the price-setting shareholder is wrong, and policymakers should consider reforms to improve the quality of information aggregation that occurs via price setting.

Whatever the interpretation, one conclusion is clear. Median shareholders and price-setting shareholders exhibit disparate preferences for management control relative to dissident control of corporations subject to proxy contests. Voting and price setting are aggregating information in very different ways.

Goshen (2004), and Feddersen and Pesendorfer (1997). While these models explain why shareholder voting may not aggregate information so as to maximize shareholder value, they cannot explain management's advantage relative to dissidents. 


\section{References}

Bainbridge, Stephen M. 2006. "Director Primacy and Shareholder Disempowerment," 119 Harvard Law Review 1735-58.

Bebchuk, Lucian. 2005. “The Case for Increasing Shareholder Power," 118 Harvard Law Review 833-914.

Bebchuk, Lucian. 2007. "The Myth of the Shareholder Franchise," 93 Virginia Law Review 675-732.

Bebchuk, Lucian Arye, and Oliver D. Hart. 2001. "Takeover Bids vs. Proxy Fights in Contests for Corporate Control." Harvard Law and Economics Discussion Paper No. 336; and ECGI-Finance Working Paper No. 04/2002. Available at SSRN http://ssrn.com/abstract=290584 or DOI: $10.2139 /$ ssrn. 290584 .

Bethel, Jennifer, and Stuart L. Gillan. 2002. "The Impact of the Institutional and Regulatory Environment on Shareholder Voting," 31 Financial Management 2954.

Brav, Alon, Wei Jiang, Frank Partnoy, and Randall S. Thomas. 2007. "Hedge Fund Activism, Corporate Governance, and Firm Performance," ECGIFinance Working Paper No. 139/2006. Available at SSRN http://ssrn.com/ abstract $=948907$.

Chava, Sudheer, and Michael R. Roberts. 2008. "How Does Financing Impact Investment? The Role of Debt Covenant Violations," 43 Journal of Finance 2085-121.

Choi, Stephen J., Jill E. Fisch, and Marcel Kahan. 2008. Director Elections and the Role of Proxy Advisors. U of Penn, Inst for Law \& Econ Research Paper No. 08-18. Available at SSRN http://ssrn.com/abstract=1225963.

Cremers, Martijn, and Roberta Romano. 2007. "Institutional Investors and Proxy Voting: The Impact of the 2003 Mutual Fund Voting Disclosure Regulation," ECGI-Law Working Paper No. 83/2007. Available at SSRN http://ssrn.com/abstract $=982493$.

DeAngelo, H., and L. DeAngelo. 1989. "The Role of Proxy Contests in the Governance of Publicly-Held Corporations," 23 Journal of Financial Economics $29-59$.

Deaton, Angus. 1997. The Analysis of Household Surveys: A Microeconomic Approach to Development Policy. DC: World Bank Publications.

Dodd, P., and J. Warner 1983. "On Corporate Governance: A Study of Proxy Contests," 11 Journal of Financial Economics 401-38.

Easterbrook, Frank, and Daniel Fischel. 1983. "Voting in Corporate Law," 26 Journal of Law and Economics 395-427.

Edelman, Paul, and Randall Thomas. 2005. "Corporate Voting and the Takeover Debate," 58 Vanderbilt Law Review 453-98.

Feddersen, Timothy, and Wolfgang Pesendorfer. 1997. "Voting Behavior and Information Aggregation in Elections with Private Information," 65 Econometrica 1029-58. 
Georgeson Shareholder Communications Inc. 2000-2006. Annual Corporate Governance Report. Gorgeson Shareholder. http://www.georgesonshareholder.com/ usa/resources_research.php.

Gerber, Alan, and Neil Malhotra. 2008. "Do Statistical Reporting Standards Affect What Is Published? Publication Bias in Two Leading Political Science Journals," 3 Quarterly Journal of Political Science 313-26.

Gilson, Ronald, and Alan Schwartz. 2001. "Sales and Elections as Methods for Transferring Corporate Control," 2 Theoretical Inquiries in Law 1-32.

Goshen, Zohar. 2004. "Voting (Sincerely) in Corporate Law," 5 Theoretical Inquiries in Law 1-23.

Harris, Milton, and Artur Raviv. 1993. "Differences of Opinion Make a Horse Race," 6 Review of Financial Studies 473-506.

$\mathrm{Hu}, \mathrm{H}$. , and B. Black. 2006. "The New Vote Buying: Empty Voting and Hidden (Morphable) Ownership," 79 Southern California Law Review 811908.

Ikenberry, David, and Josef Lakonishok. 1993. "Corporate Governance through the Proxy Contest: Evidence and Implications," 66 Journal of Business 405-35.

Imbens, G. 2007. "Regression Discontinuity Designs," Lecture 3: What's New in Econometrics." http://www.nber.org/WNE/lect_3_rd_fig.pdf (accessed October 12, 2009).

Imbens, Guido W., and Thomas Lemieux. 2007. "Regression Discontinuity Designs: A Guide to Practice," (April 2007). NBER Working Paper No. W13039. Available at SSRN: http://ssrn.com/abstract=980422.

Kamar, Ehud. 2006. "Does Shareholder Voting on Corporate Acquisitions Matter." Working paper, American Law and Economics Association Annual Meeting.

Lipton, Martin, and William Savitt. 2007. "The Many Myths of Lucian Bebchuk," 93 Virginia Law Review 733-58.

Listokin, Yair. 2008. "Management Always Wins the Close Ones," 10 American Law and Economics Review 159-84.

Macey, Jonathan. 2007. "Too Many Notes and Not Enough Votes: Lucian Bebchuk And Emperor Joseph II Kvetch About Contested Director Elections and Mozart's Seraglio," 93 Virginia Law Review 759-72.

MacKinlay, A. C. 1997. "Event Studies in Economics and Finance," 35 Journal of Economic Literature 13-39.

Manne, Henry. 1965. "Mergers and the Market for Corporate Control," 73 Journal of Political Economy 110-20.

Martin, S., and F. Partnoy. 2005. "Encumbered Shares," 2005 University of Illinois Law Review 775-814.

McCrary, Justin. 2007. "Manipulation of the Running Variable in the Regression Discontinuity Design: A Density Test," (January 2007). NBER Working Paper No. T0334. Available at http://ssrn.com/abstract $=956851$. 
Mulherin, J. Harold, and Annette Poulsen. 1998. "Proxy Contests and Corporate Change: Implications for Shareholder Wealth," 47 Journal of Financial Economics 279-313.

Pound, John. 1988. "Proxy Contests and the Efficiency of Shareholder Oversight," 20 Journal of Financial Economics 237-65.

Prabhala, N. R. 1997. "Conditional Methods in Event Studies and an Equilibrium Justification for Standard Event-Study Procedures," 10 Review of Financial Studies $1-38$.

Rauh, Joshua D. 2006. "Investment and Financing Constraints: Evidence from the Funding of Corporate Pension Plans," 61 Journal of Finance 33-71.

Romano, Roberta. 2003. "Does Confidential Proxy Voting Matter?," 32 Journal of Legal Studies 465-509.

Young, Peyton. 1988. "Condorcet's Theory of Voting," 82 American Political Science Review 1231-44. 